\title{
Keefektifan Bimbingan Klasikal Metode Jigsaw untuk Meningkatkan Komunikasi Interpersonal Siswa
}

\author{
Giovanda Ghufronalazuardy ${ }^{1}$ dan Muslikah ${ }^{2}$ \\ 1,2 Program Studi Bimbingan dan Konseling, Universitas Negeri Semarang \\ e-mail: giovanda28@gmail.com
}

\begin{abstract}
ABSTRAK. Penelitian ini bertujuan untuk mengetahui keefektifan bimbingan klasikal metode jigsaw untuk meningkatkan komunikasi interpersonal siswa SMA Negeri 4 Kota tegal. Metode penelitian ini menggunakan penelitian eksperimen dengan menggunakan desain pre-experimental one group pretest-posttest design. Subjek pada penelitian ini adalah siswa kelas XI IPA 3 SMA Negeri 4 Kota Tegal dengan jumlah sampel 30 siswa yang diambil menggunakan teknik simple random sampling. Teknik pengumpulan data yang digunakan dalam penelitian ini adalah skala psikologi dengan instrumen skala komunikasi interpersonal siswa. Analisis data menggunakan analisis deskriptif kuantitatif dan uji beda (t-test). Hasil penelitian menunjukkan bahwa rata-rata komunikasi interpersonal siswa sebelum diberikan perlakuan sebesar 133,6 (kategori rendah) dan setelah diberikan perlakuan meningkat menjadi 238,8 (kategori sangat tinggi). Berdasarkan uji beda (t-test) dengan $\mathrm{N}=30$ dan taraf kesalahan 5\% diketahui bahwa thitung $>$ ttabel $(17,128>2,042)$, maka Ha diterima dan Ho ditolak. Pada penelitian ini, dapat disimpulkan bahwa bimbingan klasikal metode jigsaw efektif digunakan untuk meningkatkan komunikasi interpersonal siswa SMA Negeri 4 Kota Tegal
\end{abstract}

Kata kunci: bimbingan klasikal; komunikasi interpersonal; metode jigsaw

\section{Pendahuluan}

Komunikasi interpersonal merupakan proses interaksi yang terjadi diantara dua orang secara tatap muka, yang memungkinkan setiap orang menangkap reaksi orang lain secara langsung. Perkembangan komunikasi dikemukakan oleh Hany (2000) komunikasi dalam kehidupan menjadi jembatan untuk mengantar kita pada berbagai kebutuhan. Pada kehidupan sehari hari, kita lebih banyak menghabiskan waktu untuk berkomunikasi dari pada beraktivitas yang lainnya. Dapat dipastikan bahwa kita berkomunikasi hampir di semua aspek kehidupan. Oleh karna itu kemampuan komunikasi yang baik sangat di butuhkan agar setiap individu dapat menjalin hubungan antar manusia dengan baik dan tidak terisolir di lingkungan masyrakat di mana dia tinggal.

Disisi lain kegagalan komunikasi tersebut bisa dicontohkan pada remaja Sekolah Menengah Atas (SMA) bahwa pada masa remaja ini mereka sudah mulai memasuki tahap dewasa awal dan sudah mulai timbul akan kesadaran mengenai kepribadiannya sendiri. Proses yang sangat berarti dalam fase remaja yang juga akan mempengaruhi fase perkembangan berikutnya adalah terjadinya komunikasi sosial dengan individu lain. Proses tersebut merupakan hal terpenting dari setiap tugas masa perkembangan, karena dengan melakukan komunikasi, individu akan belajar toleransi dan belajar mengenal dan memahami persamaan ataupun perbedaan yang ada dalam kehidupan. 
Kemudian melalui wawancara terhadap Guru Bimbingan dan Konseling, yang saya temukan di lapangan sangatlah berbeda. Wawancara yang saya lakukan pada siswa di SMA Negeri 4 Kota Tegal menemukan khususnya kelas XI laki-laki sering memanggil nama teman mereka dengan sebutan yang tidak baik misalkan: iteng, koplak. Bahkan terkadang mereka memanggil dengan nama panggilan orangtua dan ketika saya masuk ke kelas siswa itu sangat pasif sekali untuk bertanya atau mengajukan pertanyaan kepada guru. Berdasarkan hasil pengamatan dan wawancara terhadap Guru Bimbingan dan Konseling terdapat siswa yang memiliki kesulitan melakukan komunikasi interpersonal, yang diindikasikan adanya perilaku komunikasi interpersonal siswa yang kurang baik dengan teman sekelas dan kelas lainnya, banyak siswa yang menyendiri serta mereka cenderung lebih bersifat individu. Kemudian ketika berkomunikasi dengan teman sebaya cenderung mengeluarkan kata-kata yang kurang baik serta membedabedakan teman. Selain itu, masih ada siswa yang kurang terbuka dalam mengungkapkan masalahnya kepada teman dan guru bimbingan dan konseling karena ada perasaaan malu, sungkan dan takut. Menurut Pribadi, Goeritno dan Utami (2015) dampak yang terjadi pada remaja tersebut sering kali mengalami kekacauan identitas, yaitu sindrom masalah-masalah yang meliputi terbaginya gambaran diri, ketidakmampuan menjalin persahabatan yang akrab, tidak bisa berkonsentrasi, kurang memahami pentingnya waktu, dan menolak nilai-nilai yang berlaku pada keluarga dan masyarakat.

Usaha untuk membantu mengembangkan kemampuan komunikasi interpersonal siswa di sekolah dapat dilakukan melalui layanan bimbingan dan konseling. Salah satunya ialah bimbingan klasikal, bimbingan klasikal dipandang tepat digunakan pada layanan bimbingan dan konseling yang dapat diberikan kepada siswa yang belum memiliki kemampuan komunikasi interpersonal yang efektif. Melalui bimbingan klasikal diharapkan siswa secara optimal mendapatkan pemahaman dan perubahan untuk mencapai kemampuan perkembangan komunikasi interpersonal yang positif. Kesitawahyuningtyas dan Padmomartono (2014) menjelaskan bahwa Bimbingan klasikal yaitu layanan bantuan untuk siswa yang jumlah siswa antara 20-40 orang melalui kegiatan klasikal yang disajikan secara sistematik, bersifat pengembangan dan preventif serta dapat untuk mengupayakan pemahaman diri dan pemahaman tentang orang lain yang berorientasi pada 3 bidang pembelajaran yaitu, pribadi, sosial dan karir dengan tujuan untuk menginformasi yang akurat, serta dapat membantu individu untuk merencanakan pengambilan keputusan dalam hidupnya dan mengembangkan potensi secara optimal. Sedangkan menurut Fatimah (2017) bimbingan klasikal merupakan bagian yang memiliki pengaruh besar dalam layanan bimbingan dan konseling, serta merupakan layanan yang efisien, terutama dalam menangani masalah rasio jumlah konseli dan konselor.

Salah satu metode yang dapat digunakan yaitu metode Jigsaw, siswa diharapkan mampu menghayati tokoh-tokoh (peran) atau posisi yang dikehendaki keberhasilan siswa dalam menghayati peran itu akan menentukan apakah proses pemahaman tentang Jigsaw di kelompok ahli dapat di sampaikan dengan benar di kelompok yang asalnya. Menurut Widyastuti (2017) Jigsaw merupakan model pembelajaran kooperatif dimana siswa belajar dalam kelompok kecil yang terdiri dari 4-6 orang secara heterogen dan bekerja sama saling ketergantungan yang positif dan bertanggung jawab atas ketuntasan bagian materi pelajaran yang harus dipelajari dan menyampaikan materi tersebut kepada anggota kelompok yang lain. 
Selain itu menurut Illa Suryaningsih dan Drs. Mohamad Nursalim (2016) dalam pembelajaran kooperatif (teknik Jigsaw) guru mengajarkan kepada siswa untuk berkolaborasi atau mengenai kemampuan sosialnya sehingga siswa dapat bekerjasama dengan lebih efektif. Tentu saja kerjasama bukan hanya sebuah cara dari sebuah pembelajaran, namun juga sebuah hal atau tema tentang berkomunikasi dan belajar. Kemampuan sosial yang dimaksud ialah mengetahui pendapat dari yang lain, meminta yang lain untuk berpendapat, dan menjaga ketenangan saat berdiskudi atau dalam sebuah percakapan.

Berdasarkan pengertian para ahli diatas, metode jigsaw memiliki kelebihan yaitu menurut Suprihatin (2017) kelebihan metode Jigsaw, berikut diuraikan sebagai berikut: (1) Dapat mengurangi rasa kantuk dibanding belajar sendiri, (2) Dapat merangsang motivasi belajar, (3) Ada tempat bertanya, (4) Kesempatan melakukan resitasi oral,dan (5) Dapat membantu timbulnya asosiasi dengan perisitwa lain yang mudah diingat

Dari penjelasan diatas, penelitian ini bertujuan untuk mengetahui tingkat komunikasi interpersonal siswa SMA Negeri 4 Kota Tegal sebelum mengikuti bimbingan klasikal metode jigsaw, mengetahui tingkat komunikasi interpersonal siswa SMA Negeri 4 Kota Tegal sesudah mengikuti bimbingan klasikal metode jigsaw, serta mengetahui perbedaan tingkat komunikasi interpersonal siswa sebelum dan sesudah mengikuti bimbingan klasikal metode jigsaw

\section{Metode}

Penelitian ini menggunakan metode penelitian eksperimen dan menggunakan desain preexperimental one-group pretest-posttest design. Melalui bentuk desain ini, peneliti melakukan pengukuran sebanyak dua kali. Pengukuran pertama dilakukan untuk mengukur komunikasi interpersonal siswa sebelum diberikan perlakuan (pretest) dan pengukuran kedua dilakukan untuk mengukur komunikasi interpersonal siswa sesudah diberikan perlakuan (posttest). Setelah dilakukan pengukuran, peneliti membandingkan hasil pengukuran dari pretest dan posttest.

Pada penelitian ini menggunakan dua variabel, yaitu variabel independen $(X)$ dan variabel dependen $(\mathrm{Y})$. Variabel independen $(\mathrm{X})$ dalam penelitian ini adalah bimbingan klasikal metode Jigsaw. Sedangkan untuk variabel dependen (Y) dalam penelitian ini adalah komunikasi interpersonal. Subjek pada penelitian ini adalah siswa kelas XI IPA 3 yang berjumlah 30 siswa. Dalam pengambilan sampel peneliti menggunakan teknik simple random sampling.

Metode pengumpulan data yang digunakan dalam penelitian ini adalah skala psikologis. Menurut Anwar dalam (Sutoyo, 2014: 151) skala psikologis digunakan sebagai alat ukur yang memiliki karakteristik khusus untuk mengungkap konstruk atau konsep skala psikologis yang menggambarkan aspek kepribadian individu seperti : tendensi agresifitas, sikap terhadap sesuatu, self esteem, kecemasan, persepsi, dan motivasi. Dalam kaitannya dengan penelitian ini, skala psikologis digunakan untuk mengukur tingkat komunikasi interpersonal siswa sebelum maupun sesudah pemberian treatment (perlakuan) layanan bimbingan klasikal metode Jigsaw. Analisis data yang digunakan pada penelitian ini menggunakan analisis deskriptif kuantitatif dan uji t-test 


\section{Temuan}

Berikut ini merupakan hasil dari pretest kelas XI IPA 3 secara menyeluruh dari skala psikologi komunikasi interpersonal sebelum diberikan layanan bimbingan klasikal metode jigsaw.

Tabel 1. Hasil Pretest

\begin{tabular}{cccc}
\hline No & Interval & Kriteria & Jumlah \\
\hline 1 & $223-265$ & Sangat Tinggi & 0 \\
2 & $180-222$ & Tinggi & 0 \\
3 & $137-179$ & Sedang & 15 \\
4 & $94-136$ & Rendah & 8 \\
5 & $51-93$ & Sangat Rendah & 7 \\
\hline
\end{tabular}

Berdasarkan data tabel 1 tersebut dapat diketahui hasil pre-test komunikasi interpersonal siswa sebelum diberikan layanan bimbingan klasikal metode Jigsaw dengan rata-rata skor yang didapat dari hasil pre-test komunikasi interpersonal secara keseluruhan sebelum diberikan layanan bimbingan klasikal metode Jigsaw yaitu 133,6. Dimana skor tersebut dalam rumus kurve normal termasuk dalam kategori rendah. Kemudian peningkatan komunikasi interpersonal siswa kelas XI IPA 3 ini diberikan dengan layanan bimbingan klasikal metode Jigsaw selama 6x pertemuan yang setelah itu diberikan post-test.

Tabel 2. Hasil Posttest

\begin{tabular}{cccc}
\hline No & Interval & Kriteria & Jumlah \\
\hline 1 & $223-265$ & Sangat Tinggi & 18 \\
2 & $180-222$ & Tinggi & 12 \\
3 & $137-179$ & Sedang & 0 \\
4 & $94-136$ & Rendah & 0 \\
5 & $51-93$ & Sangat Rendah & 0 \\
\hline
\end{tabular}

Berdasarkan data tabel 2 tersebut dapat diketahui hasil post-test komunikasi interpersonal siswa sesudah di berikan layanan bimbingan klasikal metode Jigsaw dengan rata-rata skor yang didapat dari hasil post-test komunikasi interpersonal secara keseluruhan sesudah diberikan layanan bimbingan klasikal metode Jigsaw yaitu 238,8. Dimana skor tersebut dalam rumus kurve normal termasuk dalam kategori Sangat Tinggi.

Dengan demikian, diketahui bahwa terjadi peningkatan komunikasi interpersonal siswa sebelum dan sesudah diberikan bimbingan klasikal metode jigsaw. Adapun hasil komunikasi interpersonal siswa sebelum dan sesudah diberikan bimbingan klasikal metode jigsaw perindikator dapat dilihat pada tabel 3 .

Tabel 3. Hasil Skor Sebelum dan Sesudah diberikan Bimbingan Klasikal metode Jigsaw Per indikator

\begin{tabular}{|c|c|r|c|c|c|c|}
\hline \multirow{2}{*}{ No } & \multirow{2}{*}{ Indikator } & \multicolumn{2}{|c|}{ Pre Test } & \multicolumn{2}{|c|}{ Post Test } & \multirow{2}{*}{ Peningkatan } \\
\cline { 3 - 7 } & Kkor & Kriteria & Skor & Kriteria & \\
\hline 1 & Keterbukaan & 70,833 & Sangat Rendah & 137,417 & Sedang & 66,584 \\
\hline 2 & Empati & 71 & Sangat Rendah & 137,083 & Sedang & 66,083 \\
\hline
\end{tabular}




\begin{tabular}{|c|c|c|c|c|c|c|}
\hline 3 & Sikap Mendukung & 88,154 & Sangat Rendah & 137 & Sedang & 48,846 \\
\hline 4 & Sikap positif & 71,375 & Sangat Rendah & 138 & Sedang & 66,625 \\
\hline 5 & Kesetaraan & 73,625 & Sangat Rendah & 137,125 & Sedang & 63,5 \\
\hline
\end{tabular}

Hipotesis yang diajukan dalam penelitian ini adalah "bimbingan klasikal metode jigsaw efektif digunakan untuk meningkatkan komunikasi interpersonal siswa SMA Negeri 4 Kota Tegal". Untuk mengetahui keefektifan bimbingan klasikal metode jigsaw untuk meningkatkan komunikasi interpersonal siswa SMA Negeri 4 Kota Tegal dapat dilihat dari ada tidaknya peningkatan komunikasi interpersonal siswa kelas sebelum dan sesudah mengikuti bimbingan klasikal metode jigsaw. Pada penelitian ini, untuk mengetahui peningkatan komunikasi interpersonal siswa sebelum dan sesudah mengikuti bimbingan klasikal metode jigsaw dilakukan analisis data menggunakan rumus t-test. Adapun hasil analisis data menggunakan uji beda t-test dapat dilihat pada tabel 4

Tabel 4. Hasil Uji t-test

\begin{tabular}{|c|c|c|c|c|c|c|c|c|c|}
\hline & \multicolumn{5}{|c|}{ Paired Differences } & \multirow{3}{*}{$\mathrm{t}$} & \multirow{3}{*}{ df } & \multirow{3}{*}{$\begin{array}{c}\text { Sig. } \\
\text { (2-tailed) }\end{array}$} \\
\hline & & \multirow[t]{2}{*}{ Mean } & \multirow[t]{2}{*}{$\begin{array}{c}\text { Std. } \\
\text { Deviation }\end{array}$} & \multirow{2}{*}{$\begin{array}{l}\text { Std. } \\
\text { Error } \\
\text { Mean }\end{array}$} & \multicolumn{2}{|c|}{$\begin{array}{c}95 \% \text { Confidence } \\
\text { Interval of the } \\
\text { Difference }\end{array}$} & & & \\
\hline & & & & & Lower & Upper & & & \\
\hline Pair 1 & $\begin{array}{l}\text { Sebelum diberikan } \\
\text { layanan - Sesudah } \\
\text { diberikan layanan }\end{array}$ & -105.200 & 33,642 & 6,142 & $-117,762$ & $-92,638$ & $-17,128$ & 29 & ,000 \\
\hline
\end{tabular}

Berdasarkan hasil uji perhitungan t-test pada tabel 2, diketahui bahwa $t_{\text {hitung }}>t_{\text {tabel }}(17,128>$ 2,042), maka $\mathrm{H}_{a}$ diterima dan $\mathrm{H}_{\mathrm{o}}$ ditolak. Dengan demikian, terbukti bahwa bimbingan klasikal metode jigsaw efektif digunakan untuk meningkatkan komunikasi interpersonal siswa SMA Negeri 4 Kota Tegal.

\section{Diskusi}

Penelitian yang telah dilakukan ini bertujuan untuk mengetahui tingkat komunikasi interpersonal siswa SMA Negeri 4 Kota Tegal sebelum mengikuti bimbingan klasikal metode jigsaw, mengetahui tingkat komunikasi interpersonal siswa SMA Negeri 4 Kota Tegal sesudah mengikuti bimbingan klasikal metode jigsaw, serta mengetahui perbedaan tingkat komunikasi interpersonal siswa sebelum dan sesudah mengikuti bimbingan klasikal metode jigsaw. Hasil dari penelitian ini diharapkan dapat menjadi bahan tambahan referensi bagi peneliti selanjutnya yang akan meneliti kembali khususnya mengenai bimbingan klasikal metode jigsaw untuk meningkatkan komunikasi interpersonal siswa.

Berdasarkan penelitian yang telah dilakukan dapat diketahui bahwa bimbingan klasikal efektif digunakan untuk meningkatkan komunikasi interpesonal siswa SMA Negeri 4 Kota Tegal. Dengan demikian telah terbukti bahwa adanya peningkatan tingkat komunikasi interpesonal siswa di SMA Negeri 4 kota tegal. Peningkatan skor tertinggi didapat oleh indikator "Sikap Positif" sebesar 66,625. Sedangkan peningkatan skor terendah didapat oleh indikator "Sikap Mendukung" sebesar 48,846. Dari hasil tabulasi peningkatan skor ini dapat menunjukkan bahwa terdapat peningkatan komunikasi interpersonal sebelum dan sesudah diberikan layanan bimbingan klasikal metode Jigsaw. 
Hal tersebut ditandai dengan kondisi yang memperlihatkan bahwa siswa belum dapat memahami akan pentingnya komunikasi interpersonal. Selain itu, terdapat pula siswa yang beranggapan jika komunikasi interpersonal itu tidak merugikan atau hanya berdampak kecil. Sehingga komunikasi interpersonal siswa di kelas tersebut termasuk rendah. Kemudian yang terjadi pada remaja tersebut sering kali mengalami kekacauan identitas, yaitu sindrom masalahmasalah yang meliputi terbaginya gambaran diri, ketidakmampuan menjalin persahabatan yang akrab, tidak bisa berkonsentrasi, kurang memahami pentingnya waktu, dan menolak nilai-nilai yang berlaku pada keluarga dan masyarakat. Perilaku ini sering terjadi saat stres, cemas dan motivasi rendah dapat mengganggu komunikasi. Hal tersebut membuat mereka merasa dijauhi oleh teman atau dikucilkan di lingkungan, sehingga sering mengakibatkan kegagalan dalam berkomunisi dengan orang di sekitarnya.

Kemudian setelah dilihat dari hasil penelitian, dimana kategori awal siswa kelas XI IPA 3 mendapatkan kategori rendah dan setelah diberikan treatment komunikasi interpersonal menjadi sangat tinggi. Peningkatan komunikasi interpersonal ini salah satunya didukung oleh proses pemberian materi yang disertai dengan cerita nyata yang dialami pada lingkungan sekitar tentang komunikasi interpersonal. Peserta didik menjadi lebih antusias dalam mengikuti dan memahami materi yang disampaikan. Metode Jigsaw yang digunakan oleh peneliti juga terbukti dapat meningkatkan komunikasi interpersonal siswa.

Hasil penelitian ini sesuai dengan penelitian Zuhara (2015) dengan judul penelitian "Efektivitas Teknik Sosiodrama untuk Meningkatkan Komunikasi Interpersonal Siswa". Penelitian ini bertujuan menghasilkan rumusan intervensi yang efektif untuk meningkatkan komunikasi interpersonal siswa. Hasil penelitian ini menunjukan bahwa peningkatan yang signifikan, perubahan skor rata-rata kemampuan hubungan interpersonal pada saat pretest kelas kontrol sebesar (14,28\%) mengalami peningkatan menjadi (42,86\%) pada saat posttest. Sedangkan pada kelas eksperimen sebesar $(37,5 \%)$ pada saat pretest mengalami peningkatan sebesar $(62,5 \%)$ pada saat posttest. Hal ini mempunyai arti jika bimbingan klasikal efektif digunakan untuk meningkatkan komunikasi interpersonal siswa. Sejalan juga dinyatakan dalam penelitian oleh Rosidah (2017) dengan judul penelitian "Layanan Bimbingan Klasikal untuk Meningkatkan Konsep Diri Siswa Underachiver". Penelitian ini bertujuan dari penelitian ini adalah untuk menguji efektifitas pelayanan bimbingan klasik kepada konsep diri siswa underachiever. Hasil penelitian ini bahwa layanan bimbingan klasikal efektif untuk meningkatkan konsep diri siswa underachiever siswa kelas VIII SMP AlFajar Pringsewu, yang dibuktikan dengan adaanya hasil pengujian hipotesis bahwa Ho ditolak dan $\mathrm{Ha}$ diterima, dan adanya peningkatan hasil skor antara pretest dan posttest.

Berdasarkan penelitian tersebut dan hasil penelitian yang dijelaskan dapat menjawab rumusan masalah pada penelitian. Namun penelitian ini juga masih mempunyai beberapa keterbatasan dalam pelaksanaannya yaitu yang pertama terkait pengukuran tingkat komunikasi interpersonal yang diukur dengan pretest dan posttest menggunakan kisi-kisi komunikasi interpersonal. Kemudian sasaran penelitian pada beberapa penelitian sebelumnya ditujukan kepada siswa SMP sedangkan penelitian ini ditujukan kepada siswa SMA yang lebih berfikiran lebih dewasa. Hasil temuan pada penelitian ini akan menjadi pedoman atau acuan bagi guru BK disekolah agar memperhatikan siswanya dalam rangka untuk meningkatkan komunikasi interpersonal siswa yang terjadi di lingkungan sekolah. 
Berdasarkan penelitian yang telah dilakukan diperoleh hasil yang dapat menjawab rumusan masalah pada penelitian. Namun penelitian ini juga masih mempunyai beberapa keterbatasan dalam pelaksanaannya yaitu 1) Pengumpulan data yang digunakan skala psikologi dimana kemungkinan ada jawaban yang tidak sesuai dengan keadaan sebenarnya, walau demikian peneliti sudah berupaya menjelaskan kepada siswa untuk menjawab pernyataan dengan jujur dan sesuai keadaan yang sebenarnya. 2) Waktu pelaksanaan yang cukup singkat, sehingga pelaksanaan bimbingan klasikla metode Jigsaw berjalan kurang maksimal dengan waktu yang di berikan oleh guru BK. 3) Layanan klasikal dilakukan di ruang kelas, namun ruangan terlalu sempit dan panas sehingga membuat siswa merasa sangat gerah. Kemudian saran bagi peneliti selanjutnya, dapat menggunakan penelitian ini untuk rujukan pada saat melakukan penelitian selanjutnya dengan memperhatikan batasan penelitian dalam hal bimbingan klasikal menggunakan metode Jigsaw.

\section{Simpulan}

Hasil penelitian menunjukkan bahwa rata-rata komunikasi interpersonal siswa sebelum diberikan perlakuan berada pada kategori rendah dan setelah diberikan perlakuan meningkat menjadi kategori sangat tinggi. Berdasarkan uji beda (t-test) dengan $\mathrm{N}=30$ dan taraf kesalahan $5 \%$ dapat disimpulkan bahwa bimbingan klasikal metode jigsaw efektif digunakan untuk meningkatkan komunikasi interpersonal siswa SMA Negeri 4 Kota Tegal

\section{Referensi}

Fatimah, D. N. (2017). Layanan bimbingan klasikal dalam meningkatkan self control siswa SMP Negeri 5 Yogyakarta. Hisbah: Jurnal Bimbingan Konseling Dan Dakwah Islam, 14(1), 25-37.

Kesitawahyuningtyas, M. T., \& Padmomartono, S. (2014). Meningkatkan Komunikasi Interpersonal Melalui Layanan Bimbingan Klasikal Pada Siswa Kelas X Sma Negeri 1 Getasan, Kabupaten Semarang. Satya Widya, 30(2), 63-70.

Pribadi, A. S., Goeritno, H., \& Utami, C. T. (2015). Efektivitas Model Pembelajaran Kooperatif Jigsaw Untuk Meningkatkan Komunikasi Interpersonal Pada Mahasiswa Psikologi. PREDIKSI, 4(1), 1.

Rosidah, A. (2017). Layanan bimbingan klasikal untuk meningkatkan konsep diri siswa underachiver. Jurnal Fokus Konseling, 3(2), 154-162.

Septia, H., Yusmansyah, Y., \& Mayasari, S. (2014). Peningkatan Komunikasi Interpersonal dengan Menggunakan Konseling Kelompok. ALIBKIN (Jumal Bimbingan Konseling), 3(2).

Suprihatin, S. (2017). Penggaruh Model Pembelajaran Jigsaw Terhadap Hasil Belajar Studi Masyarakat Indonesia Mahasiswa. PROMOSI: Jurnal Program Studi Pendidikan Ekonomi, 5(1).

Suryaningsih, I. (2014). Penerapan Teknik Jigsaw dalam Layanan Informasi untuk Meningkatkan Kemampuan Komunikasi Interpersonal Siswa Kelas XI Tei 3 SMKN I Driyorejo, Gresik. Jurnal BK UNESA, 4(3).

Sutoyo, A. (2014). Pemahaman Individu. Yogyakarta: Pustaka Pelajar

Widyastuti, D. A. (2017). Jigsaw: Strategi Dalam Mengembangkan Keterampilan Komunikasi Interpersonal Calon Konselor. 
Yandri, H., Fikri, M. K., \& Juliawati, D. (2019). Penerapan Perilaku Altruistik dalam Layanan Konseling Individu Oleh Guru Bimbingan dan Konseling di Sekolah. Tarbawi: Jurnal Imu Pendidikan, 15(1), 53-64.

Yuniar, R. R., Juliawati, D., Jamin, A., \& Yandri, H. (2020). Interpersonal communication analysis of students at Schools that use social media in the New Normal Era. Bikotetik (Bimbingan dan Konseling: Teori dan Praktik), 4(2), 41-45.

Zuhara, E. (2015). Efektivitas teknik sosiodrama untuk meningkatkan komunikasi interpersonal siswa (penelitian kuasi eksperimen kelas X di SMA Kartika Siliwangi 2 Bandung Tahun Ajaran 2013/2014). JURNAL EDUKASI: Jurnal Bimbingan Konseling, 1(1), 80-89. 